\title{
Epizootic Epitheliotropic Disease of lake trout (Salvelinus namaycush): history and viral etiology
}

\author{
Terence M. Bradley ${ }^{1}$, Daniel J. Medina ${ }^{1}$, Pei W. Chang ${ }^{1}$, Jerry McClain ${ }^{2}$ \\ ${ }^{1}$ Department of Fisheries, Animal and Veterinary Sciences, Building 14, University of Rhode Island, Kingston, \\ Rhode Island 02881-0804. USA \\ ${ }^{2}$ Iron River National Fish Hatchery, HCR Box 44, Iron River, Wisconsin 54847, USA
}

\begin{abstract}
A previously undescribed virus was isolated by physical (non-cultural) means from juvenile lake trout (Salvelinus namaycush) undergoing epizootics of unknown etiology. The enveloped virus, which measured 220 to $235 \mathrm{~nm}$ and had a capsid diameter of 100 to $105 \mathrm{~nm}$, was extracted from moribund fish by isopycnic centrifugation and visualized by transmission electron microscopy. Virus was not found in apparently healthy fish. Horizontal transmission was demonstrated by waterborne exposure of healthy fish to $450 \mathrm{~nm}$ filtrates and to purified virus obtained by non-cultural methods from moribund fish, $100 \%$ mortality occurring within 39 and $43 \mathrm{~d}$ post-exposure, respectively. No mortalities occurred in groups of fish exposed to $220 \mathrm{~nm}$ filtrates or to $450 \mathrm{~nm}$ filtrates prepared from healthy control fish. Investigations of natural epizootics at 3 different hatcheries revealed that fry were more affected by the disease than fingerlings. Mortalities in a population of 3.2 million fry exceeded $99.7 \%$. The virus appeared to be the etiologic agent of the epizootics based on the following criteria: (1) it could be obtained only from infected fish; (2) the disease could be induced with purified virus and with filtrates from infected fish prepared with filters of appropriate porosity; (3) it produced clinical signs and lesions consistent with those observed during natural epizootics; and (4) the antibiotic oxytetracycline proved ineffective against it. The virus has been tentatively classified as a herpesvirus and named Epizootic Epitheliotropic Disease Virus, based on the propensity of the agent for epithelial cells, especially those in the epidermis.
\end{abstract}

\section{INTRODUCTION}

During the past $5 \mathrm{yr}$ cumulative mortalities, of unknown etiology, of hatchery-reared juvenile lake trout, Salvelinus namaycush, in the Great Lakes Region of the USA have exceeded 15 million. Investigations of the epizootics, which occurred at 7 hatcheries in 3 states, failed to reveal their cause (Bradley et al. 1988). McAllister \& Herman (1987) and Bradley et al. (1988) observed a chlamydia-like organism associated with some of the epizootics. The disease was characterized by a rapid increase in mortalities which followed soon after the appearance of poorly pathognomonic clinical signs including swimming in a spiral pattern, congregation and gasping at the water surface, ataxia, and lethargy interspersed with periods of hyperexcitability. Smaller fish appeared to be most affected and mortalities in hatchery populations sometimes exceeded $99 \%$.

(c) Inter-Research/Printed in F. R. Germany
In this paper, we describe the extraction, purification, and partial characterization of a previously undescribed virus obtained from moribund juvenile lake trout during epizootics. A tentative virus classification and data on the pathogenicity, transmission, and etiological role of this virus are presented. The infection associated with this virus has been provisionally designated as Epizootic Epitheliotropic Disease (EED).

\section{MATERIALS AND METHODS}

Source of iish. Juvenile lake trout measuring 6 to $12 \mathrm{~cm}$ in length and weighing 7 to $9 \mathrm{~g}$ were provided by Iron River National Fish Hatchery (Iron River, WI, USA) and Marquette State Fish Hatchery (Marquette, MI, USA). Both diseased and healthy lake trout were shipped to our laboratory in insulated containers and arrived within $24 \mathrm{~h}$ of dispatch. In addition, epizootics 
in several populations of hatchery-reared juvenile lake trout were monitored and investigated.

Extraction and purification of virus. The virus extraction procedure was carried out on diseased and on healthy, apparently uninfected fish. A $20 \%$ tissue homogenate (weight/volume) of various organs (brain, liver, spleen, kidney, pyloric caeca, stomach, intestine, skin, and gill) was prepared in phosphate buffered saline (PBS), pH 7.2, using a sterile mortar and pestle. The homogenate was clarified by centrifugation at $10000 \times g$ for $30 \mathrm{~min}$ and again at $15000 \times g$ for 30 min at $4^{\circ} \mathrm{C}$. The supernatant was passed through a $450 \mathrm{~nm}$ membrane filter, layered onto a $3 \mathrm{ml} 50 \% \mathrm{CsCl}$ cushion in a $60 \mathrm{ml}$ centrifuge tube, and centrifuged at $83000 \times g$ for $3 \mathrm{~h}$ at $4{ }^{\circ} \mathrm{C}$ using a Sorvall AH-627 rotor. A visibie band, present above the CsCi cushion, was harvested. Dry $\mathrm{CsCl}$ was added to the fraction containing the band to obtain a final density of $1.28 \mathrm{~g} \mathrm{~cm}^{-3}$. Five $\mathrm{ml}$ of the fluid were centrifuged at $210000 \times \mathrm{g}$ in a Sorvall AH-650 rotor for $18 \mathrm{~h}$ at $4{ }^{\circ} \mathrm{C}$. Following centrifugation, fractions were collected from the tube and the density of each fraction deduced from its refractive index.

Electron microscopy. Samples of each fraction were stained with $1.5 \%$ phosphotungstic acid (PTA), pH 7.0, by pseudoreplication (Smith \& Melnick 1962), and examined with a Hitachi HS-9 transmission electron microscope (TEM) operating at an acceleration voltage of $75 \mathrm{kV}$.

Effect of oxytetracycline in treatment of infected lake trout. Infected fish were collected from a population undergoing an epizootic and exhibiting clinical signs of the disease. Six groups of 20 juvenile lake trout each were maintained at $10^{\circ} \mathrm{C}$ in $40 \mathrm{l}$ aquaria equipped with aerators and external filters. The 6 tanks of fish were randomly assigned to one of the following treatments: (1) 20 infected fish; (2) 20 infected fish and oxytetracycline (OTC); (3) 15 uninfected fish exposed to 5 infected fish; (4) 15 uninfected fish exposed to 5 infected fish and OTC: (5) 20 uninfected fish; and (6) 20 uninfected fish and OTC. The OTC was added to the tanks at a concentration of $0.05 \mathrm{mg} \mathrm{ml}^{-1} \mathrm{~d}^{-1}$. This dosage has been demonstrated to produce tissue levels in channel catfish ca 5 times that of the minimum inhibitory concentration for most bacterial pathogens of fish (Nusbaum \& Shotts 1981). The OTC remained in the tanks for $5 \mathrm{~h}$ daily and was removed by filtration through activated charcoal. The condition of the fish and mortalities were recorded daily. Samples of moribund fish were processed for histopathology

Infection of juvenile lake trout with EED virus. Eighty juvenile lake trout, ca $7 \mathrm{~cm}$ long, were divided randomly into four 401 aquaria each containing 20 fish Fish in the aquaria were subjected to one of the following treatments: (1) addition of $10 \mathrm{ml}$ of filtrate (made from moribund fish and obtained by low speed centrifugation followed by filtration through a $450 \mathrm{~nm}$ filter) to 38 I aquaria; (2) as per (1) except that the filtrate was also passed through a $220 \mathrm{~nm}$ filter; (3) as per (1) except that purified virus, prepared as described in extraction and purification of virus, was used; and (4) as per (1) except that filtrate from uninfected fish, prepared as in Treatment 1 (above) was used.

The tanks were contained in an environmental chamber at $10^{\circ} \mathrm{C}$ and the fish were acclimated for $5 \mathrm{~d}$ prior to exposure. Fish were observed daily for clinical signs, morbidity, and mortality. Moribund and dead fish were processed for histopathological examination or were examined for virus using the extraction method and electron microscopy.

Species susceptibility to EED virus. The susceptibility of 5 other salmonid species (rainbow trout, Salmo gairdneri; brook trout, Salvelinus fontinalis; brown trout, Salmo trutta; Atlantic salmon, Salmo salar; and chinook salmon, Oncorhynchus tshawytscha) to EED virus was investigated. The rainbow, brook, and brown trout were maintained either in live cages within tanks containing infected lake trout or in troughs directly below infected lake trout. Thirty to 50 juvenile individuals of each species were exposed for 86 to $91 \mathrm{~d}$ to juvenile lake trout undergoing an active epizootic of EED. Water temperatures ranged from 6 to $12{ }^{\circ} \mathrm{C}$.

Juvenile Atlantic salmon and chinook salmon were exposed to EED virus by holding them in closed 951 aquaria with infected juvenile lake trout. Twenty individuals of each species were exposed for a period of $60 \mathrm{~d}$ at $10^{\circ} \mathrm{C}$. In addition, aquaria containing the same number of uninfected fish were utilized as controls.

In vitro propagation of EED virus. Propagation of EED virus was attempted in the following fish cell lines: fathead minnow (FHM) (Gravell \& Malsberger 1965); rainbow trout gonad (RTG-2) (Wolf \& Quimby 1962); chinook salmon embryo (CHSE-214) (Fryer et al. 1965); epithelioma papilosum cyprini (EPC) (Fijan et al. 1983); and rainbow trout hepatoma (RTH-149) (Fryer et al. 1981). Cell cultures were grown in Eagle minimal essential medium with Hank's balanced salt solution and $6 \%$ fetal bovine serum $(\mathrm{pH} 7.0$ to 7.3$)$ at 10 or $15^{\circ} \mathrm{C}$.

Ten percent tissue homogenates were prepared from the internal organs of diseased fish and the homogenates were clarified by low speed centrifugation and by filtration through a $450 \mathrm{~nm}$ membrane as described for the virus extraction and purification. A $0.1 \mathrm{ml}$ aliquot of the tissue fluid was inoculated onto confluent monolayers of each cell culture. The inoculated cell cultures were observed for cytopathic effects (CPE) for $21 \mathrm{~d}$. The culture fluid from the first virus passage was inoculated into a second set of cell cultures and again observed for CPE. 


\section{RESULTS}

\section{Clinical signs, gross and microscopic}

Affected fish exhibited a spiral swimming behavior, ataxia, and lethargy interspersed with periods of hyperexcitability. Gross external lesions included hemorrhaging at the base of the fins and in the lower quadrant of the eye; saprolegnia infections; and fin degeneration. On autopsy, the only gross lesion was a mild swelling of the kidney. The primary histopathological lesions observed were hyperplasia, hypertrophy, and necrosis of epidermal cells; edema of the secondary lamellae of the gills; renal tubule degeneration; and dilation of the glomeruli. Eosinophilic intranuclear inclusion bodies were observed in a number of epidermal cells.

\section{Natural epizootics}

EED virus was purified from moribund fish from 2 year classes at 3 hatcheries. Three of the 4 epizootics were associated with environmental or handling stress prior to increased mortalities. Epizootics occurred at temperatures from 6 to $15^{\circ} \mathrm{C}$ in both the spring and fall, but primarily in the spring. Fry appeared to be more susceptible to the disease than fingerlings. Mortalities in a population of 3.20 million fry reached 3.19 million individuals, ca $99.7 \%$ of the year class. In fingerlings (10 to $13 \mathrm{~cm}$ ), however, mortalities ranged from 27 to $30.5 \%$ in populations consisting of 0.5 to 2.0 million individuals. In all cases, epizootics were preceded by severe flashing and apparent respiratory distress.
Numerous remedial measures were attempted but they had negligible effects. The measures included the addition of $\mathrm{NaCl}$, formalin, benzalkonium chloride, terramycin, erythromycin, or formalin/malachite green to the hatchery water. The duration of the epizootics ranged from 2 to $3 \mathrm{mo}$. Assays of viscera from moribund fish conducted according to established procedures (McDaniel 1979) did not reveal the presence of any known fish viruses except in one epizootic in which a dual infection of EED and infectious pancreatic necrosis (IPN) viruses was found. Infections with Pseudomonas spp. and Aeromonas spp. were found in several epizootics but they were not considered to be the primary cause of mortality. In addition, branchial epitheliocystis infections were observed in fish in 3 of the 4 epizootics (Bradley et al. 1988).

\section{Virus extraction, purification, and electron microscopy}

A diffuse band with a density of 1.28 to $1.29 \mathrm{~g} \mathrm{~cm}^{-3}$ was collected from linear density gradients after isopycnic centrifugation of the concentrated tissue homogenate. Examination of this fraction by electron microscopy revealed the presence of numerous uniform and hexagonal particles with icosahedral symmetry (Fig. 1). Unenveloped particles measured 100 to $105 \mathrm{~nm}$ in diameter and appeared to have 5 capsomeres on each side of the capsid (Fig. 1). The capsomeres also appeared to have a hollow center when stained negatively with PTA (Fig. 2). Enveloped particles, 220 to $235 \mathrm{~nm}$ in diameter, were observed at a density of 1.25 to $1.26 \mathrm{~g} \mathrm{~cm}^{-3}$ (Fig. 3).
Fig. 1. Epizootic Epitheliotropic Disease Virus. Negatively stained particles isolated from moribund juvenile lake trout (Salvelinus namaycush) during an epizootic. Capsomeres are visible within the capsids. $B a r=50 \mathrm{~nm}$

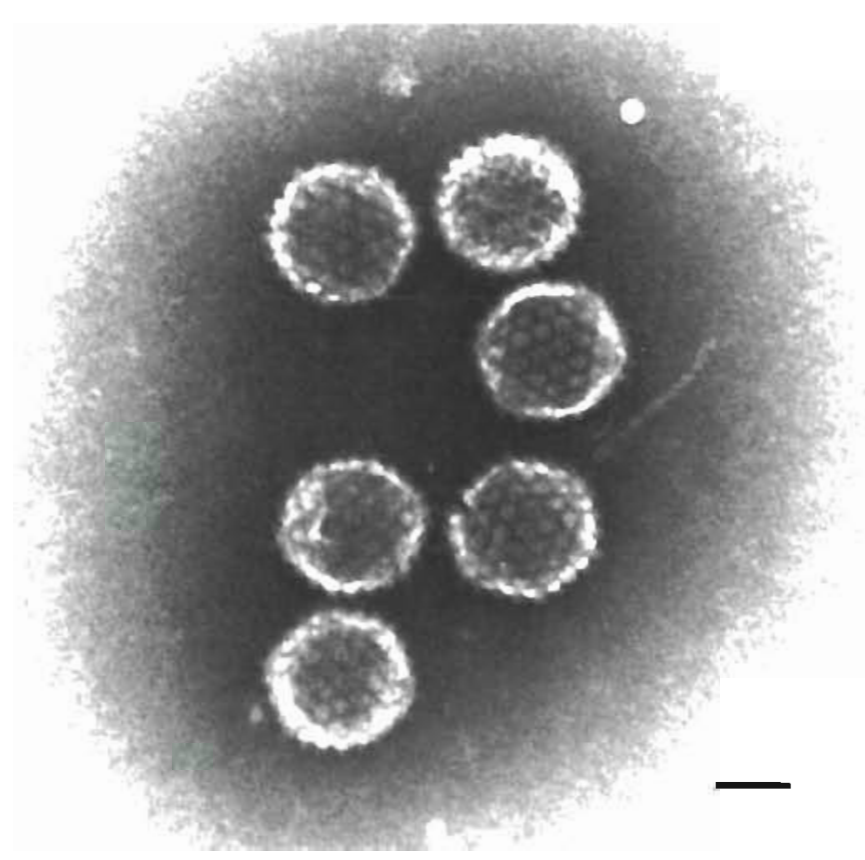



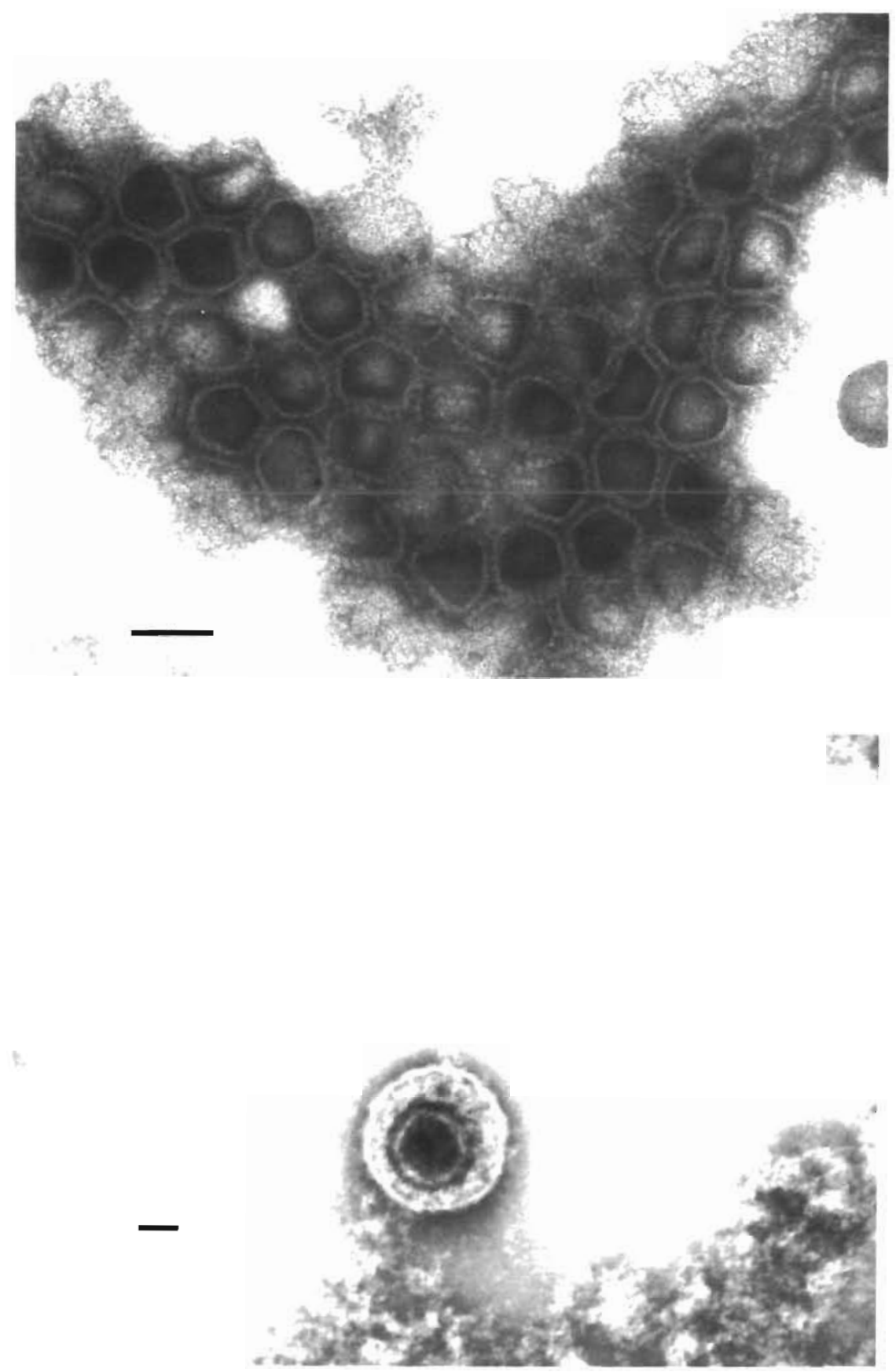

Fig. 2. EEDV Cluster of negatively stained particles showing intact and broken capsids. Free capsomeres are also present. Note hollow centers of capsomeres. Bar $=100 \mathrm{~nm}$

\section{Effect of OTC on infected lake trout}

In both infected and exposed fish, $0.05 \mathrm{mg} \mathrm{ml}^{-1}$ of OTC in the water had no therapeutic effect on diseased fish. In addition, the antibiotic did not prevent transmission of the disease from infected to uninfected fish (Table 1). One hundred percent mortality was observed in both infected and exposed fish with and without OTC treatment. In the infected fish, $100 \%$ mortality was reached in $8 \mathrm{~d}$, whereas 14 to $15 \mathrm{~d}$ were required to attain $100 \%$ mortality in exposed fish.

\section{Infection of juvenile lake trout with EED virus}

Lake trout exposed to the $450 \mathrm{~nm}$ filtrate prepared from infected fish exhibited clinical signs by Day 32 The first mortality occurred $33 \mathrm{~d}$ post-exposure with $100 \%$ mortality occurring by Day 39 post-exposure (Table 2). The first mortality in fish exposed to an undetermined titer of purified virus occurred at $35 \mathrm{~d}$ post-exposure; $100 \%$ mortality occurred in these fish by Day 43. No mortalities were observed in fish exposed to the $220 \mathrm{~nm}$ filtrate prepared from infected 
Table 1. Salvelinus namaycush. Effect of oxytetracycline (OTC) treatment on lake trout infected and exposed to Epizootic Epitheliotropic Disease Virus. Treatment consisted of 0.05 mg OTC ml ${ }^{-1} \mathrm{~d}^{-1}$ Five hours after each daily treatment, OTC was partially removed by charcoal filtration. Infected fish exhibiting clinical signs of EED were supplied by Iron River National Fish Hatchery, WI. For the exposed group 15 uninfected fish were placed in an aquarium with 5 infected fish. The first mortality of an uninfected fish occurred $10 \mathrm{~d}$ postexposure with highest mortalities on Day 12 post-exposure. Day: days post-exposure to reach $100 \%$ mortality; CM: cumulative mortality (\%)

\begin{tabular}{|lrrrr|}
\hline Treatment & $\begin{array}{c}\text { In- } \\
\text { fected }\end{array}$ & $\begin{array}{c}\text { Unin- } \\
\text { fected }\end{array}$ & Day & CM \\
\hline Infected & 20 & 0 & 8 & 100 \\
Infected + OTC & 20 & 0 & 8 & 100 \\
Exposed & 5 & 15 & 15 & 100 \\
Exposed + OTC & 5 & 15 & 14 & 100 \\
Uninfected & 0 & 20 & - & 0 \\
Uninfected + OTC & 0 & 20 & - & 0 \\
\hline
\end{tabular}

Table 2. Salvelinus namaycush. Experimental infection of juvenile lake trout $(7.3 \pm 0.8 \mathrm{~g}$ and $7.8 \pm 0.6 \mathrm{~cm}$ long) with filtered tissue homogenates and purified EED virus at $10^{\circ} \mathrm{C}$. Filtered homogenate: of internal organs, gills, and skin from diseased lake trout passed through a $450 \mathrm{~nm}$ membrane filter $(450 \mathrm{~nm})$, and with an additional passage through a $220 \mathrm{~nm}$ membrane filter $(220 \mathrm{~nm})$. Purified virus isolated by isopycnic centrifugation and visualized by transmission electron microscopy. The virus was derived from the same fish as the filtrates. Controls were exposed to a crude homogenate of

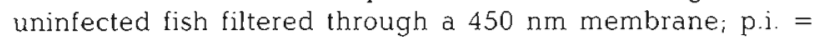
post-infection

\begin{tabular}{|ccccc|}
\hline Days p.i. & $\begin{array}{c}\text { Filtered homogenate } \\
450 \mathrm{~nm}\end{array}$ & $\begin{array}{c}\text { Purified } \\
\text { virus }\end{array}$ & $\begin{array}{c}\text { Uninfected } \\
\text { controls }\end{array}$ \\
\hline 32 & 0 & 0 & 0 & 0 \\
33 & 2 & 0 & 0 & 0 \\
34 & 3 & 0 & 0 & 0 \\
35 & 4 & 0 & 1 & 0 \\
36 & 3 & 0 & 1 & 0 \\
37 & 5 & 0 & 0 & 0 \\
38 & 0 & 0 & 0 & 0 \\
39 & 3 & 0 & 4 & 0 \\
40 & & 0 & 5 & 0 \\
41 & & 0 & 2 & 0 \\
42 & & 0 & 1 & 0 \\
43 & & 0 & 6 & 0 \\
Mortality & 100 & 0 & 100 & 0 \\
(\%) & & & & \\
\hline
\end{tabular}

fish, and control fish exposed to a $450 \mathrm{~nm}$ filtrate prepared from uninfected fish all survived. Virus was found in 2 six-fish pools prepared from the groups of fish exposed to the $450 \mathrm{~nm}$ filtrate derived from infected fish and the purified virus. No viral particles were extracted from control fish. Histological examination of moribund individuals revealed extensive hyper- plasia and hypertrophy of epidermal epithelial cells and renal lesions similar to those observed in fish during natural epizootics. In addition, intranuclear inclusion bodies were observed in epithelial cells of the skin (Fig. 4). No significant lesions were observed in uninfected control fish sampled at the termination of the study.

\section{Species susceptibility to EED virus}

During the exposure period of 86 to $91 \mathrm{~d}$, a total of 2 rainbow, 1 brook, and 1 brown trout died. Uninfected juvenile lake trout exposed to infected lake trout, utilizing the same physical design, exhibited mortalities of $>60 \%$ in $<30 \mathrm{~d}$.

Mortalities in Atlantic and chinook salmon exposed to infected lake trout were the same as those exposed to uninfected lake trout $(<5 \%)$.

\section{Propagation of EED virus in cell culture}

No CPE was produced during a $21 \mathrm{~d}$ period following the inoculation of FHM, RTG-2, CHSE-214, EPC, and RTH-149 cell lines with infected tissue fluid. CPE was not observed when the tissue culture fluid was passed a second time in these cell lines.

\section{DISCUSSION}

Our studies on the etiology of EED in lake trout lead us to conclude that a virus of the herpes group is responsible for the disease.

The consistent recovery of enveloped and unenveloped 100 to $105 \mathrm{~nm}$ hexagonal viral particles (Figs. 1 to 3) from diseased fish and the absence of these particles in uninfected fish suggest that the viral particles were responsible for EED. Further, infectivity studies using purified virus confirmed the viral etiology of the disease in accord with River's postulates (River 1937). The purified virus was demonstrated to be capable of inducing the disease in lake trout and was reextracted from infected moribund fish. Furthermore, the lesions found in experimentally infected fish were consistent with those observed in fish from natural epizootics. The failure of the $220 \mathrm{~nm}$ filtrate to produce infection may have been due to clumping of viral particles and subsequent binding to the membrane.

OTC is known to inhibit most bacteria, rickettsia, chlamydia, and mycoplasma, but not viruses. When OTC was used to treat diseased fish or prevent exposed fish from becoming infected, it was ineffective, supporting the hypothesis that the causative agent was a virus. 


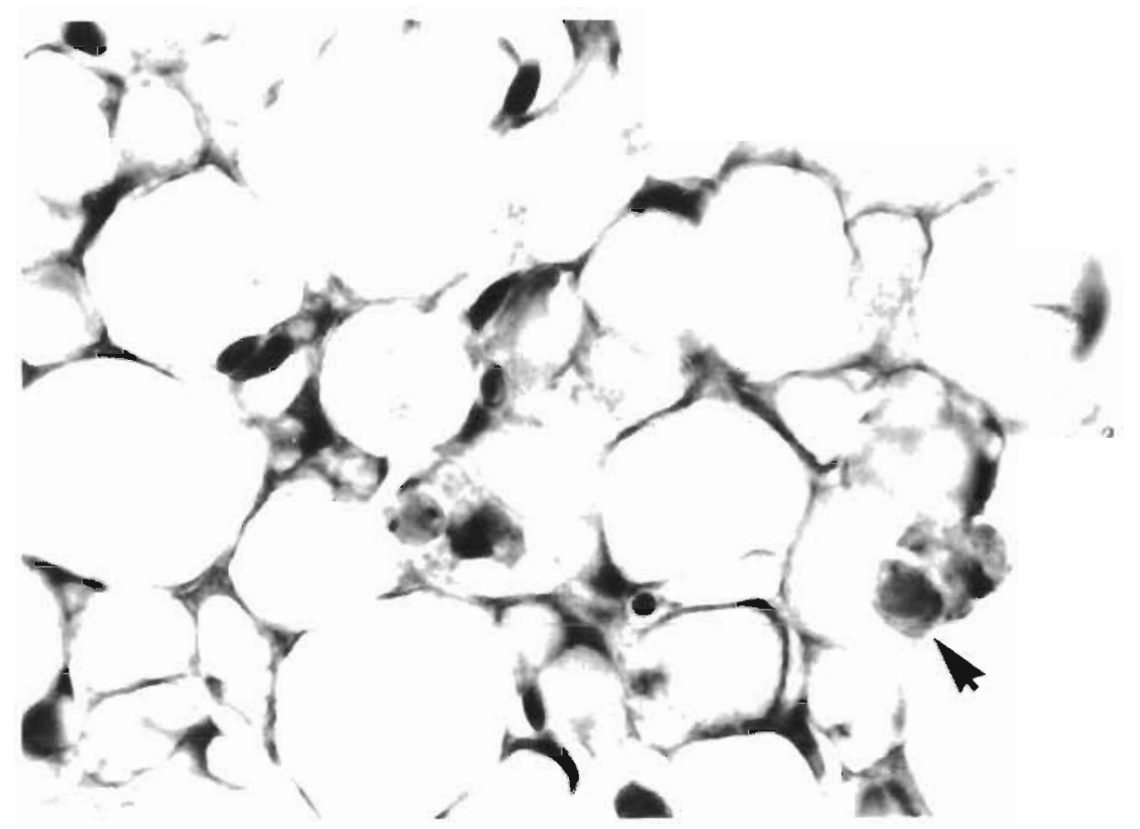

Fig. 4. EEDV. Intranuclear inclusion body (arrow) in the skin epithelium of juvenile lake trout infected with EED virus; $\times 1000$

Definitive classification of this virus requires further study. However, the number of capsomeres on one side of the capsid appears to be 5 (Fig. 1). This gives a total calculated number of 162 capsomeres which is typical of the family Herpesviridae (Wildy et al. 1960). In addition, the capsomeres appear to have a hollow center (Fig. 2), another characteristic of herpesviruses. The size of the capsid (100 to $105 \mathrm{~nm})$, and buoyant density of the naked particles $\left(1.28 \mathrm{~g} \mathrm{~cm}^{-3}\right)$ all fall within the range of herpesviruses. Although numerous naked capsids were observed, enveloped viral particles were also found. All known herpesviruses have an

Table 3. Comparison of 6 fish herpesviruses with EED virus. U: unknown

\begin{tabular}{|c|c|c|c|c|c|c|}
\hline Designation & $\begin{array}{c}\text { Common name of virus and } \\
\text { natural host }\end{array}$ & $\begin{array}{l}\text { Size of } \\
\text { capsid } \\
\text { (nm) }\end{array}$ & $\begin{array}{c}\text { No. } \\
\text { cap- } \\
\text { someres }\end{array}$ & Pathology & $\begin{array}{l}\text { In vitro } \\
\text { propagation }\end{array}$ & Source \\
\hline $\begin{array}{l}\text { Salmonid } \\
\text { herpesvirus } 3\end{array}$ & $\begin{array}{l}\text { Epizootic Epitheliotropic } \\
\text { Disease Virus } \\
\text { Salvelinus namaycush }\end{array}$ & $100-105$ & 162 & $\begin{array}{l}\text { Epidermal hyperplasia. } \\
\text { hypertrophy, and necrosis. } \\
\text { Edema in gills }\end{array}$ & None & This paper \\
\hline $\begin{array}{l}\text { Salmonid } \\
\text { herpesvirus } 1\end{array}$ & $\begin{array}{l}\text { Herpesvirus salmonis } \\
\text { Salmo gairdn:ri } \\
\text { Oncorhynchus nerká }\end{array}$ & $90-95$ & 162 & $\begin{array}{l}\text { Edema in liver, gill, } \\
\text { kidney, heart, stomach, and } \\
\text { pseudobranch. Necrosıs } \\
\text { and hemorrhage. Pancreas } \\
\text { syncytia }\end{array}$ & $\begin{array}{l}\text { RTG-2 } \\
\text { CHSE-214 }\end{array}$ & Wolf et al. (1978) \\
\hline $\begin{array}{l}\text { Salmonid } \\
\text { herpesvirus } 2\end{array}$ & $\begin{array}{l}\text { Oncorhynchus masou virus } \\
\text { Oncorhynchus masou } \\
\text { Oncorhynchus kisutch }\end{array}$ & 110 & 162 & $\begin{array}{l}\text { Epidermal hyperplasia, } \\
\text { liver necrosis, } \\
\text { tumor formation }\end{array}$ & $\begin{array}{l}\text { RTG-2 } \\
\text { CHSE-214 }\end{array}$ & $\begin{array}{l}\text { Kimura et al. } \\
(1981 \mathrm{a}, \mathrm{b})\end{array}$ \\
\hline $\begin{array}{l}\text { Ictalurid } \\
\text { herpesvirus } 1\end{array}$ & $\begin{array}{l}\text { Channel catfish virus } \\
\text { Ictalurus punctatus }\end{array}$ & 100 & 162 & $\begin{array}{l}\text { Hemorrhage, edema, } \\
\text { necrosis in kidneys, } \\
\text { hematopoietic tissue } \\
\text { and other organs }\end{array}$ & $\mathrm{BB}, \mathrm{BF}-2$ & $\begin{array}{l}\text { Wolf \& Darlington } \\
\text { (1971) } \\
\text { Wolf \& Herman } \\
\text { (1971) }\end{array}$ \\
\hline $\begin{array}{l}\text { Pleuronectid } \\
\text { herpesvirus }\end{array}$ & $\begin{array}{l}\text { Herpesvirus scophthalmus } \\
\text { (Turbot herpesvirus) } \\
\text { Scophthalmus maximus }\end{array}$ & 100 & $\mathrm{U}$ & $\begin{array}{l}\text { Epidermal hyperplasia, } \\
\text { and necrosis }\end{array}$ & None & $\begin{array}{l}\text { Buchanan and } \\
\text { Madely (1978) }\end{array}$ \\
\hline $\begin{array}{l}\text { Cyprinid } \\
\text { herpesvirus (?) }\end{array}$ & $\begin{array}{l}\text { Carp pox virus } \\
\text { Cypnnus carpio }\end{array}$ & 110 & $\mathrm{U}$ & $\begin{array}{l}\text { Chronic epidermal } \\
\text { hyperplasia and } \\
\text { hypertrophy }\end{array}$ & None & Schubert (1966) \\
\hline $\begin{array}{l}\text { Percid } \\
\text { herpesvirus } 1\end{array}$ & $\begin{array}{l}\text { Walleye epidermal } \\
\text { hyperplasia virus } \\
\text { Stizostedion vitreum }\end{array}$ & $>100$ & U & $\begin{array}{l}\text { Epidemal hyperplasia } \\
\text { and necrosis with } \\
\text { syncytia formation }\end{array}$ & WC-1, WO & Kelly et al. (1983) \\
\hline
\end{tabular}


envelope (Wildy et al. 1960, Wolf 1973, 1982). The large number of naked capsomeres may be explained by the fragile nature of the herpesvirus envelope (Wildy et al. 1960). Exposure to $\mathrm{CsCl}$ and PTA during purification and staining may have caused envelope removal from many particles. The presence of intranuclear inclusion bodies (Fig. 4) in epithelial cells provides additional evidence for classification as a herpesvirus.

The similarities and differences between EEDV and 6 known fish herpesviruses are presented in Table 3 . In general, EEDV is similar in size of viral capsid, number of capsomeres, presence of an envelope, and tissue tropism and pathology to most other fish herpesviruses However, there are differences with respect to host specificity and in vitro propagation. The present study indicates that FHM, RTG-2, CHSE-214, EPC and RTH149 cell lines do not support growth and propagation of the virus. The RTG-2 and CHSE-214 cell lines have been demonstrated to support propagation of salmonid herpesviruses Types 1 and 2 (Table 3). EEDV also appears to be very host specific and did not affect the 5 other salmonid species investigated. In addition, EEDV causes acute mortalities whereas salmonid herpesvirus Type 1 rarely causes mortalities. In contrast to salmonid herpesvirus Type 2 which causes tumor formation in survivors, no tumors were observed in lake trout chronically infected with EEDV. Based on the information provided, it appears that EEDV belongs to the family Herpesviridae. As such, we are tentatively classifying EEDV as salmonid herpesvirus Type 3. However, it is essential that an in vitro system for propagation and assay of the EED virus be established in order to fully characterize and classify the virus.

Acknowledgements. The authors thank J. Driver, J. Hnath (Michigan Dept Natural Resources), and S. Marquenski (Wisconsin Dept Natural Resources) for their assistance in this study. We also thank M. Mann for assistance in preparation of the manuscript. This research was supported in part by U.S Fish and Wildlife Service Cooperative Agreement No. 14-160009-88-923. R.I. Agricultural Experiment Station Contribution No. 2470

\section{LITERATURE CITED}

Bradley, T M., Newcomer, C. E., Maxwell, K. O. (1988) Epitheliocystis associated with massive mortalities of cultured lake trout Salvelinus namaycush. Dis. aquat. Org 4: $9-17$

Buchanan, J. S., Madeley, C. R. (1978). Studies on herpesvirus scophthalmi infection of turbot, Scophthalmus maximus (L.). Ultrastructural observations. J. Fish Dis. (Oxford, England) 1: 283-295

Responsible Subject Editor: Dr T. Evelyn, Nanaimo, B.C., Canada
Fijan, N., Sulimanovic, D., Bearzott, M., Muzinic, D., Zwillenberg, L. O., Chilmoncyk, S., Vautherot, J. F., de Kinkelin, P. (1983). Some properties of the Epithelioma Papilosum Cyprini (EPC) cell line from carp Cyprinus carpio. Ann. Virol. (Inst. Pasteur) 134E: 207-220

Fryer, J. L., McCain, B. B., Leong, J. C. (1981). A cell line derived from rainbow trout. (Salmo gairdneri) hepatoma Fish Pathol. 15: 193-200

Fryer, J. L., Yusha, A., Pilcher, K. S. (1965). The in vitro cultivation of tissue and cells of Pacific salmon and steelhead trout. Ann. N.Y Acad Sci. 126: 566-586

Gravell, M., Malsberger, R. G. (1965). A permanent cell line from the fathead minnow (Pinephales promelas). Ann. N.Y. Acad. Sci. 126: 555-565

Kelly, R. K., Nielsen, O., Mitchell, S. C., Yamamoto, I (1983) Characterization of Herpesvirus vitreum isolated from hyperplastic epidermal tissue of walleye, Stizostedion vitrium vitrium (Mitchill). J. Fish Dis. (Oxford, England) 6: 249-260

Kimura, T., Yoshimizu, M., Tanaka, M. (1981a). Studies on a new virus (OMV) from Oncorhynchus masou. II. Oncogenic nature. Fish Pathol. 15: 149-153

Kimura, T., Yoshimizu, M., Tanaka, M., Sannohe, H. (1981b) Studies on a new virus (OMV) from Oncorhynchus masou I. Characteristics and pathogenicity. Fish Pathol. 15 143-147

McAllister, P. E., Herman, R. L. (1987). A chlamydia-like organism associated with high mortality in hatchery-reared lake trout (Salvelinus namaycush). FHS/AFS Newsletter 15: 6

McDaniel, D. (ed.) (1979). Fish health blue book: procedure for the detection and identification of certain fish pathogens. Fish health section. American Fisheries Society, Bethesda

Nusbaum, K. E., Shotts, E. B., Jr (1981). Absorption of antimicrobic drugs from water by channel catfish (Ictalurus punctatus). Can. J. Fish. aquat. Sciences 38: 993-996

River, $T$ (1937). Viruses and Koch's postulates. J. Bact. 33: $1-12$

Schubert, G. H. (1966). The infective agent in carp pox. Bull Off Int. Epizoot. 65: 1011-1022

Smith, K. O., Melnick, J. L. (1962). A method for staining virus particles and identifying their nucleic acid type in the electron microscope. Virology 17· 480-490

Wildy, P., Russell, W. C., Horne, R. W. (1960). The morphology of herpes virus. Virology 12: 204-222

Wolf, K. (1973). Herpesviruses of lower vertebrates. In: Kaplan, A. S. (ed.) The Herpesviruses. Academic Press. New York, p. 495-520

Wolf, K. (1982). Biology and properties of fish and reptilian herpesviruses. In: Roizman, B. (ed.) The Herpesviruses, Vol. 2. Plenum Press, New York, p. 319-366

Wolf, K., Darlington, R. W. (1971). Channel catfish virus: a new herpesvirus of ictalurid fish. J. Virology 8: 525-533

Wolf, K. Darlington, R. W., Taylor, W G., Quimby, M. C. Nagabayashi, $T$ (1978). Herpesvirus salmonis: characterization of a new pathogen of rainbow trout. J. Virology 27 : 659-666

Wolf, K., Herman, R. L. (1971). Fish viruses: histopathologic changes associated with experimental channel catfish virus disease. J. Fish. Res. Bd Can. 29: 149-150

Wolf, K., Quimby, M. C. (1962). Established eurythermic line of fish cells in vitro. Science, N.Y 135: 1065-1066

Manuscript first received: October 10, 1988

Revised version accepted: September 22, 1989 